\title{
THE IMPLEMENTATION OF MASSIVE OPEN ONLINE COURSES FOR TRAINING FUTURE ENGINEERS IN HIGHER EDUCATION
}

Valerii HAVRYSH, Mykolayiv National Agrarian University, Ukraine Ilona BATSUROVSKA, Mykolayiv National Agrarian University, Ukraine Nataliia DOTSENKO, Mykolayiv National Agrarian University, Ukraine Antonina KALINICHENKO*, University of Opole, Poland

Received: 16. 3. 2019 / Accepted: 8. 8. 2019

Typ článku: Teoretická studie

DOI: $10.5507 /$ jtie.2019.007

Abstract: This paper investigates the features of the implementation, conduct, analysis and prospects for the use of massive, open online courses. The article deals with the main advantages and disadvantages of massive open online courses, presents a comparative analysis of research into implementation of massive, open online courses. The article outlines the basic course requirements. It contains an analysis of the current state of such courses in higher educational institutions. The article presents a number of recommendations for the development of the education system towards democratization of higher education.

Key words: massive open online courses, distance learning, e-learning, learning environment, educational activity.

\section{IMPLEMENTACE MASIVNÍCH OTEVŘENÝCH ONLINE KURZŮ V RÁMCI PŘÍPRAVY BUDOUCÍCH INŽENÝRŮ}

Abstrakt: Tento článek se zaměruje na výzkum podminek implementace, způsobů realizace a představeni perspektiv využití MOOC kurzů. Zabývá se hlavními výhodami a nevýhodami a prezentuje výzkumně založenou srovnávaci analýzu implementace těchto kurzù. Jsou nastíněny základni požadavky na kurzy a provedena analýza současné situace na vysokých školách. Závěrem je vyvozena r̆ada doporučení pro individualizaci vysokoškolského vzdělávání.

Klíčová slova: masivní otevřené online kurzy, distanční vzdělávání, e-learning, vzdělávací prostředí, vzdělávací aktivita.

*Autor pro korespondenci: kalinichenko a@ukr.net 


\section{Introduction}

Reflecting upon modern trends in education over the past decade, distance learning has become an integral part of education and information culture around the world. Practice of its implementation has opened up new prospects for spreading knowledge and giving educational opportunities for millions of people and has become an effective instrument of modernization for education systems to meet the new economic and sociocultural conditions. However, numerous studies have shown that distance learning isn't inferior to a traditional one, and sometimes it is better.

It should be noted that the methods and techniques of distance learning are based on students' self-regulating the speed of there learning, adjusting the direction of their future self-education and, most importantly, they are based on interactions best suited for distance learning. The average graduate is able to study printed textbooks (textbooks, reading books, and methodical manuals) himself because the methodology of working with these learning tools is introduced to him at school. Practical skills with applications are taught in the school course "Fundamentals of Informatics". The use of audio and video also does not cause any difficulties. However, the most problematic aspect of distance learning is the use of information and computer technology. Secondary school is not yet able to master the methods of culture and ethics of online interaction, rules of conduct, business-writing skills, which is necessary for the exchange of electronic messages in distance learning system. Furthermore, from a psychological point of view the work in distance learning system requires considerable willpower, mental effort, perseverance, etc. There are still problems developing motivation for a large number of students and teachers; rejection of the absence of direct contact with the teacher; the insufficient level of information readiness (willingness to search, percept, study information using a variety of resources); monitoring of the effectiveness and quality of education taking into account the psychological characteristics of students; lack of self-education skills and self-reflection skills required at all stages of distance learning, especially at the beginning.

\section{Methods of research}

The level of methodological and technological research was provided by: methods of theoretical analysis and synthesis, systematization, periodization, classification, analogy, principles of problem and integrity.

The complex of methods used in the research process is represented by: theoretical methods - the study and analysis of psycho-pedagogical, methodological literature, as well as information resources of the Internet - for determining problems and features of training in the conditions of mass open distance courses, formation of the personality of future engineers in the conditions of mass and open study of learning material; forecasting, formalization, categorical and logical analyzes for the purpose of educational and scientific training of future engineers and generalization of the obtained results and experience.

\section{Problem formulation}

The modern concept of lifelong education is particularly important. This is a response to a challenge that world throws us. It is the world where changes occur very quickly. For everyone, lifelong education has to become a process of forming and meeting his cognitive requests, spiritual needs, development of skills in various educational institutions through various forms of education and by self-education, self-development (Carey, 2012). Lifelong education has evolved in practice and as a pedagogical concept. Taking into 
account the scale and complexity of distance learning, a wide range of educational services, forms and organization models for its implementation and building at a high-level we need to solve many difficult conceptual problems. Including, among others, the quality of distance learning, which has been the most controversial (Volkova, 2002).

\section{Implementation of massive open online courses for training future engineers in higher education}

The object of this study is massive open online courses (MOOC). The subject of the analysis are methods and learning tools through MOOC. The quality assurance of higher education belongs to the most urgent contemporary issues among many others problems of education.

The analysis of current research. The basis for determining the nature of distance learning lies in the works of both foreign (Becker, 2000) and Ukrainian researchers (Bykov, Kukharenko, 2008;). However, the readiness of students for such individualized process of acquiring knowledge, skills and methods of human cognitive activity, which mainly occurs through mediated interactions, educational process participants who are distant from each other in a specialized environment that operates on the basis of modern psycho-pedagogical, information and communication technologies are set to on side. In distance education the role and requirements of teachers and students are changing. Many teachers and parents do not know the specifics of distance organized training.

We understand the open distance learning as a system that provides active communication between teacher and student with the use of modern technologies and multimedia. Its purpose is to provide educational services, with the help of teaching modern information and communication technologies, for specific educational or educational levels in accordance with state educational standards; training programs for citizens to enter the educational institution, training foreigners and qualification extension. Distance learning, by A. Andreev's definition (2013) - is a form of education and at the same time, a set of educational technologies for delivering the bulk of the study materials to students; interaction between students and teachers in the process of learning, providing students opportunities for the self-study of the material, as well as in the process of studying.

The use of mass open online courses is widely used in foreign teaching practice. The basis of this trend is the work of George Siemens (2005) (connectionism theorist). The results of these courses can be found in the publications of other authors. In CIS countries relevant studies and similar courses were not observed. However, there was an attempt to hold such open courses in 2011 in Ukraine.

One of the most famous Ukrainian Massive Open Online Courses (MOOC) is the platform "Prometheus". It was founded in October, 2014, as a non-profit nongovernmental organization in Kyiv, Ukraine. Main goal of the platform is to develop an open space for any of Ukrainian universities, schools, organizations and single persons to create their own MOOCs. The organizers of the Prometheus run business analytics, logistics, finance, smart cities and other courses. Molchanovskyi and Primachenko (2015) discussed the possibility to participate in the process of development thematic OR MOOC environment in Ukraine in order to highly increase quality of education of Ukrainian students and professionals in the relevant fields. The "Prometheus" already has a few successful projects and an ambitious goal - to revolutionize Ukraine's education by introducing a mixed system of studying. Prometheus has a lot in common with the world- 
known platform for online education Coursera. But Prometheus is not a commercial platform, it is non-profitable organization. And while Coursera gives a platform for the online courses of universities, companies etc, $80 \%$ of courses in Prometheus are its own ones (Shandra, 2017). Prometheus has a core team, but a lot of the work is also done by volunteers who translate and promote the courses. Another aim of this platform is to solve the problems of Ukrainian educational system such as a lack of qualified teachers, time and financing. Ukrainian professor V. Kuharenko (2013) held the plenty of online courses, for example 'Social Services in distance learning', 'Strategy of Distance Learning in the Organization', ,Distance Learning from A to Z', ,Designing Online Courses' etc. Researchers highlighted the following advantages and disadvantages of massive open online courses.

'Iversity' is online education platform. It has specialised in providing online courses and lectures in higher education, specifically MOOCs (Massive Open Online Courses). Courses are free and open for anyone to enroll and participate. Iversity cooperates with professors from European universities.

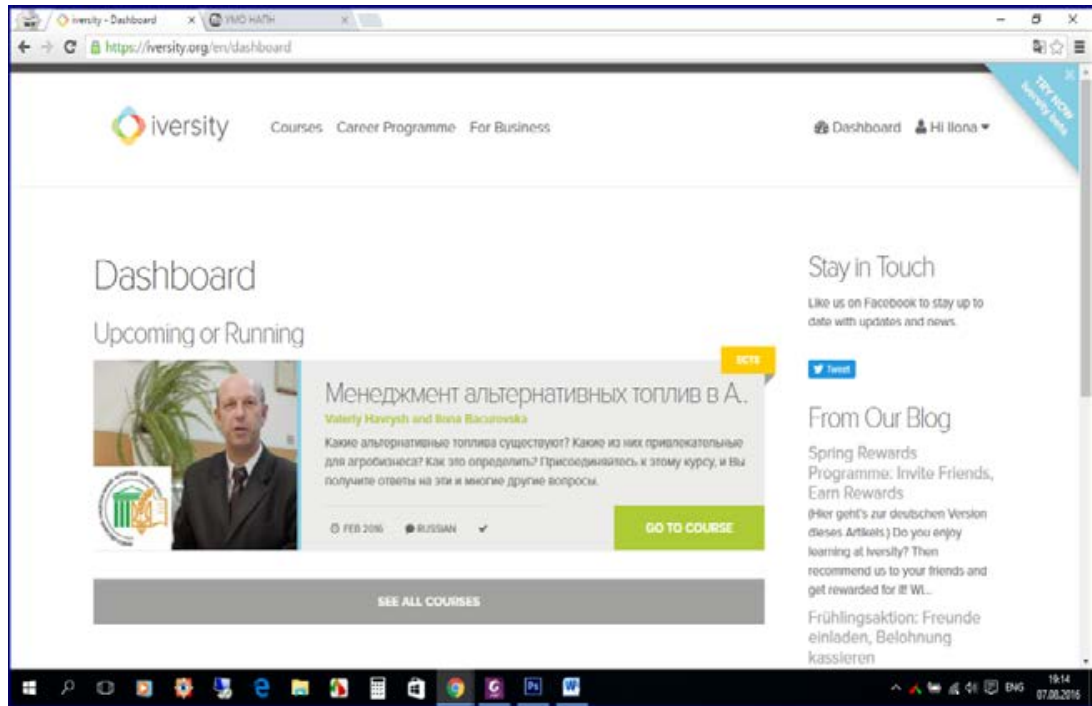

Figure no. 1: The international massive open online courses platform 'Iversity'.

Also the examples of the Ukrainian massive open online courses platform are 'Cloud 365’ (fig. 2). 


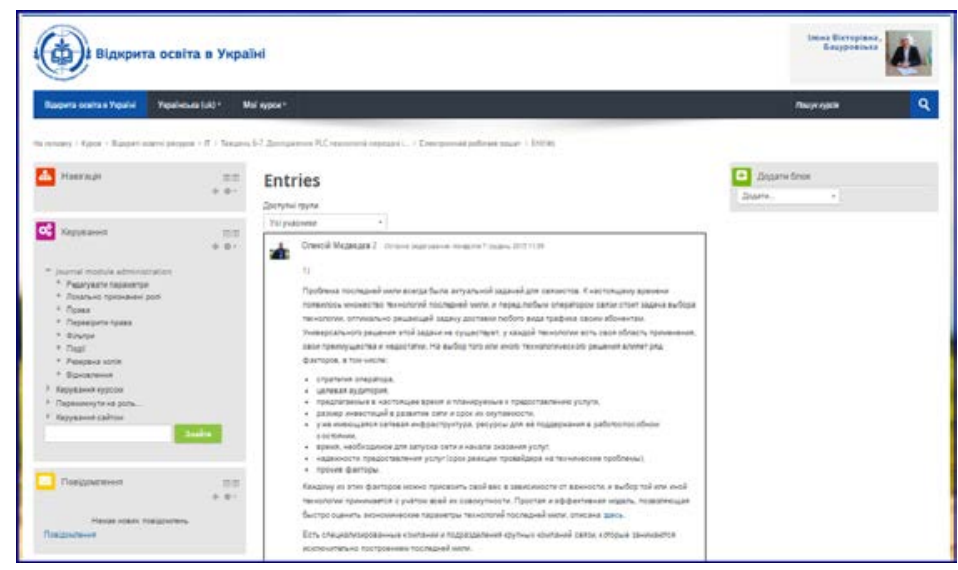

Figure no. 2: The Ukrainian massive open online courses platform 'Cloud 365'.

Various elements of content presentation can be used in massive open online courses (fig. 3, 4).

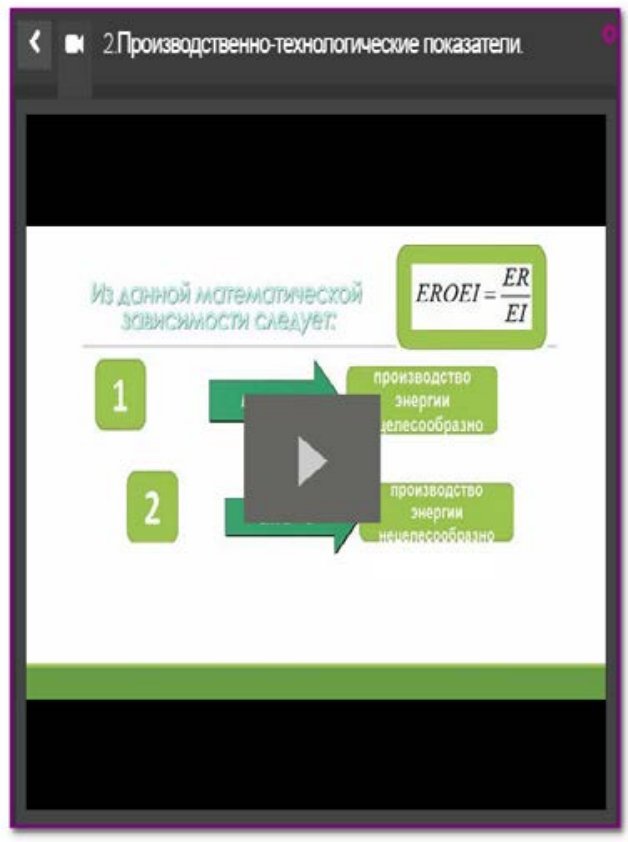

Figure no. 3: Video as an element of content presentation in a massive open online course. 


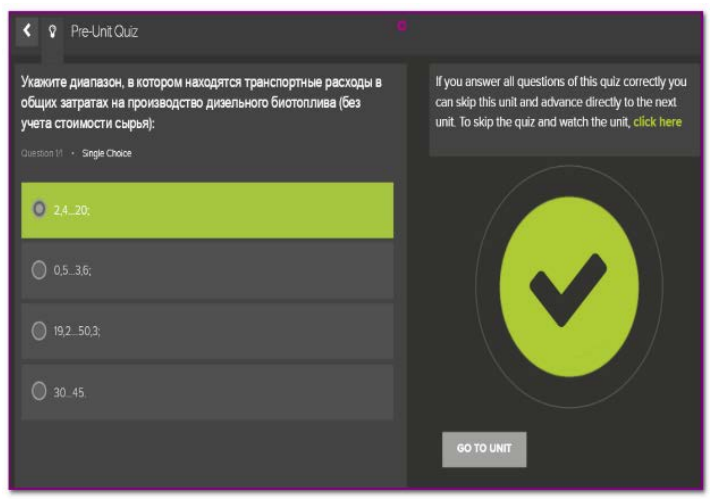

Figure no. 4: Test as an element of content presentation in a massive open online course.

Advantages:

1. The possibility of such a course anywhere where there is available communication (internet or a local connection, for example, Wi-Fi).

2. The possibility of courses in any language (including the basic language of your intended audience).

3. The ability to use any online tools that are relevant to your intended audience or participants that are already used in daily and professional activities.

4. The possibility of transcending time zones and physical boundaries.

5. The possibility of such a rapid organization of such course that is equal to the speed of post about its beginning.

6. Education occurs in a more informal setting.

7. Content can be open to all.

8. Training is provided due to informal knowledge created in the course through the exchange of information and experience between its members.

9. The possibility to use these courses as well as in a corporate and in the academic sector.

10. The possibility of creating their own personal learning environment and own personal learning network with the help of participants of the course.

11. The possibility to improve participants' skills for lifelong learning, because these courses force them to improve and develop.

12. At the end of the course, information is not removed. These created educational networks are more stable.

Disadvantages:

1. Randomness and a large amount of information.

2. Education in MOOC requires computer skills.

3. Each participant determines his educational goals and self-regulates his activities.

4. Each participant builds his own trajectory for the course. 


\section{Discussion of the results}

Also there is an interesting example of Ukrainian MOOC is "Getting knowledge" platform (2008-2019). This online resource offers students distance learning courses, consultations and lessons (GN, 2018). This educational online resource was created by Vinnitsa city center of students'distance learning and the Agency of Information and Communication Technologies. The portal is open to all users interested in this field and to potential authors of courses. Each new course passes expert assessment and requires from authors really high professional level.

Taking into account all predictions about MOOC given by the US and the UK, we can distinguish the following positive aspects of courses.

First, massive online courses attract talented speakers and entrepreneurs willing to share their knowledge and experiences with students from all over the world completely free. At the same time, instructors cannot provide individual control to each student. Due to the lack of control about $90 \%$ of students who enrolled in MOOC, drop out.

The next risk is reducing the profit and the number of working places in traditional schools if the rate of MOOC will be counted for academic credits. But it seems that teaching online classes cannot displace a university education in the near future.

It may seem that MOOC courses solve the problem of insufficient financing of higher education, but it this is not so. Many of those who signed up for online learning, already have a degree and they use distance learning course as a hobby. On the other hand, the situation can change if the MOOC will be included into the academic course as a complementary resource (Ross et al., 2014).

MOOC can be useful for the students as the possibility to test different educational programs. Also online course can be useful to those who have linked his professional career with some industry and want to improve their knowledge in a particular field. MOOC is certainly useful for improving self-esteem: someone who passed through online learning, is able to do something that $90 \%$ of the registered users are unable to do.

Today distance learning in school is implemented atan experimental level.

According to the order of Ministry of Education and Science of Ukraine (29.12.2009 № 1231) The department of research and design of the learning environment IITZN Pedagogical Sciences of Ukraine an experiment in distance learning for students was conducted (Project Supervisor - dr Y.N. Bohachkov) from March 1, 2009 to September 30, 2011. Kyiv schools and other schools from different regions of Ukraine took part in the project. Conceptual statements of the experiment and the obtained results allowed them to optimize the process of implementing distance learning in mainstream education in Ukraine.

Also there is interesting online system "Getting knowledge" for remote learning support in schools, lyceums, gymnasiums in Ukraine. This educational online resource was created by Vinnitsa city center of students' distance learning and the Agency of Information and Communication Technologies, which operates in the physicmathematical Vinnitsa school №17. The site is part of the information-educational environment in which the creators dream "load" the whole educational process in physicmathematical Vinnitsa school №17, and then - in all schools in the region, and then throughout Ukraine. This online resource offers students distance learning courses, consultations and lessons. The portal is open to all users interested in this field and to potential authors of courses. Each new course passes expert assessment and requires from authors really high professional level. 
Implementation of the elements of distance learning in school requires from teachers educational activities with the use of new technologies, testing and implementation of new learning techniques. The introduction of distance learning is impossible without the use of ICT as a tool that helps to expand opportunities for both students and teachers, and to make a decisive impact on the process of changing and improving education. The use of advanced ICT changes the role of the teacher, encourages them to introduce new teaching methods and approaches in preparation for the lesson. Such qualities as the ability to apply innovative ways to use computers and the opportunities it provides, a high level of technical literacy enhancement and new knowledge are quite important for the development of cognitive activity. Teachers should master the techniques and DL technologies at a professional level, become tutors, and to pass the necessary training and education for this purpose. You can pass courses for tutors (teachers in distance learning) in "Remote Academy". It is important for teacher to acquire skills to design his own course and to be able to organize distance learning. Today massive online courses are only convenient and accessible for gaining knowledge or extending qualifications. However, this form of education is developing rapidly. Tomorrow school graduate may ask: If I can get a better university diploma for little money, why should I enter a less prestigious one? This is a threat to Ukrainian universities in the regions. Therefore, our universities must act quickly in order to compete with the best institutions worldwide. Even leading American, European universities are concerned about the rapid development of online education. Here is an example: "There is the prestigious Georgia Institute of Technology in the USA. A few months ago it offered the world's first master's program in computer science based on online courses. They plan to provide education for ten thousand people at the same time within this program. Due to the online format of this program, to obtain Master's Degree will be seven times cheaper than usual. Of course, not all knowledge can be passed "virtually". Individual approach and work in research laboratories are required for many specialties. What about technical universities? Do they have to refuse new forms and methods of education? Massive online courses are only one of a great variety of education forms. Today they work out blended format, or as they called "hybrid" courses. For example, Massachusetts Institute of Technology (one of the best polytechnic universities in the world) offers the online circuitry course for various universities in the US. These lectures are very similar in all universities. Americans decided not to repeat the same thing. This is the principle opportunity to improve the quality of education in the country. Education will benefit if the best professors read online lectures and teachers work directly with students.

Lack of budget funding is not only a Ukrainian problem. It exists in universities in many countries. However, the "cry" for lack of money is not accepted in the world. Respect those who are trying to solve the problem. In California (USA), for example, lack of funding has led to a drop in the number of "budget places". As a result, there was a huge virtual "queue" of those who want to get an education.

Experts claim that online education spreads faster than any other technology in history. Currently, experimental projects turn into "chain" of related courses. Recently, the head of the project EdX Anand Agarwal said "the issue of obtaining diplomas in online education will be decided during the year”. Kyiv National University also will not stand aside. In the nearest future they will develop courses in law, political science, and computer science. In the nearest future they will develop courses in law, political science, computer science. We have some reasons for optimistic future in the "education revolution" in Ukraine. The most 
fundamental one is that people understand the importance of education and new knowledge."

\section{Conclusions and prospects for further research}

The problem of quality of e-learning courses is extremely important. The distance course must correspond to the main didactic principles. They include scientific content, availability, systematic presentation of educational material, adaptability, visibility, connection with practice, completeness (integrity), interactive, self-consciousness, the development of intellectual capacity and so on. An ergonomic quality is one of the requirements for distance learning courses. Requirements for color characteristics, spatial placement of information on the screen, sound, alphanumeric symbols and signs requirements, requirements of dialogue etc. are worth mentioning. Undoubtedly, the development of e-learning courses must attract leading scientists of the country, qualified scientists, educators, psychologists and programmers. It is necessary that all courses have to pass specific certification.

We believe that only this approach to distance education in the near future will make it versatile, efficient, cost-effective and affordable, will reveal and realize all its potential opportunities for the development of national education system towards democratization of higher education.

\section{References}

Andreev, A.A. (2013). E-learning and distance learning technologies. Open Education, 5(100), pp. 40-46.

Becker, H. J. (2000). Pedagogical Motivations for Student Computer Use That Lead to Student Engagement. Educational Technology, 40(5), pp. 5-17.

Bykov, V. Yu., Kukharenko, V. M. (Eds.) (2008). Technology of Distance Course Development. Kyiv: Milenium. On line [03.12.18], http://dl.khpi.edu.ua/pluginfile.php/29481/mod_resource/content/1/TCDK-

Kuxarenko_PDF.pdf

Carey, K. (2012). Into the Future with MOOC. Chronicle of Higher Education, pp. 3-9.

Kop, R. (2011). The challenges to connectivist learning on open online networks: Learning experiences during a massive open online course. The International Review of Research in Open and Distance Learning, 12(3), pp.19-38.

Kukharenko, V.(2013). Massive open online courses in Ukraine._IEEE 7th International Conference on Intelligent Data Acquisition and Advanced Computing Systems (IDAACS) (12-14 Sept. 2013). On line [03.12.18], https://ieeexplore.ieee.org/document/6663027 Molchanovskyi O., Primachenko I. (2015) Creating possibilities for open and unlimited OR education: the first Ukrainian Massive Open Online Courses platform "Prometheus" On line [13.02.19], https://www.euro-online.org/conf/euro27/treat_abstract?paperid=2919 GN - Online Platform 'Getting knowledge' (2018). On line [13.02.19], https://disted.edu.vn.ua/

Ross, J., Sinclair, C., Knox, J., Bayne, S., Macleod, H. (Eds.). (2014). Teacher Experiences and Academic Identity: The Missing Components of MOOC Pedagogy and other. MERLOT. Journal of Online Learning and Teaching, 10(1), pp.57-69.

Siemens, G. (2005). Connectivism: A Learning Theory for the Digital Age. On line [03.12.18], http://www.itdl.org/journal/jan 05/article01.htm 
Shandra, A. (2017). The Ukrainian online learning platform that wants to revolutionize the country's education. On line [13.02.19], http://euromaidanpress.com/2017/12/05/theukrainian-online-learning-platform-that-wants-to-revolutionize-the-countrys-education/ Volkova, N. P. (2002). Pedagogy. K .: Type. Center "Academy", On line [03.12.18], http://pedagogy.lnu.edu.ua/departments/pedagogika/library/volkova.pdf 